\title{
Cultivation of Intercultural Communication Competence for Business English Majors
}

\author{
Feipeng Li, Lei Dong \\ College of Foreign Languages Education and International Business, Baoding University, Baoding, China \\ Email: lfp19801104@163.com
}

How to cite this paper: Li, F. P., \& Dong, L. (2021). Cultivation of Intercultural Communication Competence for Business English Majors. Open Journal of Business and Management, 9, 752-760. https://doi.org/10.4236/ojbm.2021.92039

Received: February 22, 2021

Accepted: March 20, 2021

Published: March 23, 2021

Copyright $\odot 2021$ by author(s) and Scientific Research Publishing Inc. This work is licensed under the Creative Commons Attribution International License (CC BY 4.0).

http://creativecommons.org/licenses/by/4.0/ (c) (i) Open Access

\begin{abstract}
With economic globalization speeding up, China has increasingly frequent interaction with the world economy. A multitude of versatile talents are in urgent need who not only have good grasp of linguistic and business knowledge but also are competent in intercultural communication. Students of business English are significant resource of international business talents. This thesis discusses the principles of cultivating students' intercultural communication competence from the perspective of systematicness, practicality and comparison. Then the strategies and approaches on how to realize the improvement of the ICC of business English majors in universities and colleges are explored from five aspects including teaching syllabus, teachers' development, teaching materials, teaching modes and evaluation system. In the final part of the thesis, the author analyzes the limitation of the study and considers researching plan for further study to acquire more findings.
\end{abstract}

\section{Keywords}

Intercultural Communication, Competence, Business English, Principles, Strategies

\section{Introduction}

With the fast development of globalization, China is increasingly involved in international affairs and plays a more and more important role in the world. English, as an international language, has a great impact on business affairs. For the sake of meeting the need for business talents, a series of curricula and majors concerning business English have been set in many universities. Because of the difference in values, social regulations and cultures between China and western countries, there tend to be cultural conflicts and communicative obstacles in actual communications. Therefore, it is critical for business majors to fully under- 
stand the cultural background, living customs and social regulations of target language countries, strengthen the sensibility for cultural differences, and emphasize the cultivation of intercultural communication consciousness.

National Standard for Undergraduate Teaching Quality of Business English Majors in Colleges and Universities pointed out that the major of business English is aimed at cultivating compound and applied talents that possess solid language basic skills, international horizons and humanistic qualities, grasp basic theories and knowledge of foreign language literature, applied economics, business administration and laws, and have the ability of business English application, intercultural communication, business practice, critical thinking skills and autonomous learning. Language application ability and intercultural communication ability are the core competence of business English majors (Wang, 2015).

However, it has been shown by a number of research and surveys that students of business English major universally lack deep understanding and cognition of intercultural communications and capacity of autonomous learning (Yang, 2015). Therefore, it is urgent for universities to strengthen the reform intensity and incorporate intercultural knowledge into every link of teaching in order that students can comprehensively improve their English application ability and get proficient in intercultural exchanges and communication. This research will provide business English teachers with key principles of teaching and effective approaches, which will play a role of "throwing a minnow to catch a whale".

As a theoretical research, this thesis firstly combs and analyzes relevant theories and concepts, and it also conducts an overall literature review about the research status at home and abroad. The second part of this thesis discusses three principles of cultivating intercultural communication competence. In the fourth part, the thesis focuses on strategies of developing ICC of business English majors from the perspective of curriculum, teachers, teaching materials, teaching modes and evaluation. The final part makes conclusions and analyzes the limitations of the research.

\section{Literature Review and Theoretical Foundations}

From the perspective of anthropology, Kroeber and Kluckhorn (1954) think that culture includes various kinds of explicit or implicit behavior patterns, and they wrote an article in which they listed at least 164 definitions of culture. Chen Guoming (1989) regards communication as an interactive process. That is to say, communication is s developmental and orderly process of exchanging symbols anything more than the mere process. Hu Wenzhong (1999) holds a similar view that communication is a process of transmission and acceptance of information, during which one sends the information and the other receives the information. Edward T. Hall's The Silent Language published in 1959 is regarded as the classic foundation work of intercultural communication. Some scholars argue that intercultural communication is the process of communication under- 
taken by people who are from different cultural backgrounds. Chen and Starosta (2000) have found that the purpose of intercultural communication is to avoid cultural misunderstandings.

Kim (2001) published the book Becoming Intercultural: A Integrative Theory of Communication and Cross-cultural Adaptation, in which the term "intercultural communication competence" is preferred. Wiseman defined intercultural communication competence as one sort of competence to perform communicative behavior appropriately and effectively in a given context to achieve an ideal reaction. In China, the academic study on the cultivation if ICC did not begin until the early 1980s. One of the worth-mentioning figures in this field is $\mathrm{Hu}$ Wenzhong, who has published a series of books and articles on ICC. He gives his views on ICC from different perspectives and emphasized the importance for learners to pay close attention to cultural differences in intercultural communication.

In terms of college students of business English major and their status quo of ICC, Zeng Wenxiong (2002) made a research to investigate 140 business English undergraduates' ICC in Guangdong University of Foreign Language and found that participants are in a middle level of ICC and put forward related suggestions to improve business English teaching. Some scholars focused their research on the development of business English teachers' professional abilities. Zhang Xunyuan (2020) thinks that a certain proportion of teachers concentrate more on the teaching of English language points than penetration of cultural background and international business customs. Shen Xueen (1997) argues that trade is not only the simple exchange of commodities but also cultural exchange between different countries or nations. Hu Guolin (2008) holds that only the students, learn both the skill of expressing English and the cultural connotation and pragmatic rules of business English can they be qualified for the communication of crass-cultural business English. Zhao Jingjing (2020) carried out the research on the cultivation of ICC under the paradigm of "curriculum-integrated ideological and political education" and put forward that both China's emotions and international horizon cannot be neglected in the cultivation of students' ICC.

\section{Principles of Cultivating ICC of Business English Majors}

\subsection{Principle of Systematicness}

Lack of coherent and systematic culture infiltration is a universal problem in the process of teaching. It is very common that most English teachers just teach some cultural knowledge without explanation or explosion in detail when they meet relevant content or points. For instance, there is an important concept named pragmatic failure in the field of intercultural communication. Teachers may just simply tell students that many people make mistakes in the use of target language because of cross-culture. Actually, it is necessary for them to further introduce and interpret in detail the concept of pragmatic failure, pragmalinguistic failure and sociopragmatic failure, thus making students form systematic 
recognition of pragmatic failure. Besides, there are not unified contents and regulation of method to the teaching of culture in the syllabus and teaching requirements. Therefore, a syllabus targeting foreign language cultural introduction and specialized courses on intercultural communication need to be designed. Only in this way can teachers realize systematic introduction of culture and teaching of intercultural communication based on syllabus.

\subsection{Principle of Comparison}

Native language culture both has positive transfer and negative transfer in the learning of target language culture in the process of teaching. Teachers should make full use of the positive transfer of native language. For example, it is a good way for teachers to utilize the principle of comparison to guide students to learn about the similarities and differences between Chinese and western cultures in order to deepen students' understanding of the two kinds of cultures and avoid pragmatic failures caused by cultural transfer in communication. The teaching and comparing of Chinese and western cultures will help students to consciously apply the way of communication in accordance with target language culture to communicate efficiently. Teachers are recommended that they should help students to overcome the negative transfer of mother tongue in the process of teaching. For example, there are much more passive voices in English writing than in Chinese writing. In the teaching of business letter writing, teachers should introduce and analyze the cultural and thinking differences behind the use of different voices of language in order to lower the influence of negative transfer of mother tongue to a minimum.

\subsection{Principle of Practicality}

The principle of practicality is that the introduction of culture should be carried out based on teaching materials and the requirements for students' communication in daily life. The teaching contents of culture should closely stick to the contents that are needed for life or for the improvement of intercultural communication ability. It is required that English teachers combine language and cultural knowledge with the demands of students in their ordinary life and pay close attention to the improvement of their intercultural capacity. In addition, teachers are supposed to connect business language closely with business culture, which is helpful for students to understand the information of implicit culture in language learning thus accumulating Chinese and western culture knowledge.

\section{Strategies of Cultivating ICC of Business English Majors}

\subsection{Strengthening Scientificity and Systematicness of Curriculum}

Scientificity and systematicness are essential to the curriculum of business English. Business English should not only integrate culture into each subject, but also include culture-oriented courses, the professional courses of which should 
comprise three fields including English, business and cross-culture. The basic modules can be divided into several modules consisting of linguistic module, the business knowledge module, the intercultural communication and interpersonal communication module, and the comprehensive quality module. Each module can be composed of several core courses. All of them are complementary to establish a course system, aiming at developing the capacity of students to conduct business communication in English.

Besides scientific curriculum of knowledge, the curriculum of practical training should be emphasized. The construction of practical training is required to be built based on the principle of application-oriented, skill cultivation and practicability. For instance, various training forms can be adopted like expert interviews and field research to enterprise. The training courses of business English include cross-cultural negotiation, pronunciation, foreign trade letter writing and so on. Researchers and scholars can develop relevant teaching software through which the real materials in business activities such as the trade procedure of business negotiation and online payment are conveyed to students in form of picture, sound and scripts. In this way students can experience in a real scene, interact in the demonstration and practice in the simulation, thus becoming business English applied talents possessing high intercultural communication abilities.

\subsection{Adopting Diversified Teaching Modes}

Teachers should adopt diversified and blending teaching mode in order to improve students' intercultural business communication ability. The "two subjects" concept of teaching in international business English should be applied to international communication teaching in China, that is, the theory and method of "student-oriented" and "learning-oriented". Teacher is the conductor and promoter of class, while students are the subjects of class. Therefore, communicative approach and task-based approach are good choices in class, under which students can be encouraged to express their viewpoints and communicate with each other. As for teachers, it is their responsibility to help students carry out communicative activities, thus inspiring them to make full use of their knowledge to communicate efficiently. Meanwhile, through open-ended teaching activities teachers can get all-round understanding of students' learning demands of various levels, construct environment of intercultural communication, and establish teaching modes full of teacher-students interactions.

Case analysis teaching approach is another effective method in business English teaching. Teachers choose representative and neoteric cases, then students acquire intercultural business knowledge through debating, during which students are guided to find out some ideas to solve the problems. What should be paid close attention to is that teachers just present the case to students and instruct them to study and discuss without any hints or listing relevant points of cultural difference. By the end of debate the representatives of each group make 
concluding statements. As to this kind of teaching activity, it is much more important to analyze and think than to get correct keys to the questions.

Apparently, classroom is not the single place to cultivate students' ICC. Extra-class activities are equally important and should be well arranged. For example, role-play and task-based activities in different contexts are other significant forms because such activities enable students to obtain hands-on experience. Another option is to recommend English newspapers published by foreign news agencies for students. By reading them, learners of business English can be acquainted with foreign cultures to better understand foreigners' sense of value, ways of conducting business and behavior. Many audio-visual media such as movies, cartoon films, TV series, and commercials can also lend themselves to extra-class use. These media are excellent sources of authentic spoken language in context, and also are good resources for both language and culture.

\subsection{Construction of Teaching Faculty and Staff}

The developing level and effect of educational reform lie in teachers. The ability and level of faculties straightly determine the teaching effect. In order to cultivate business English interdisciplinary talents with strong ability of intercultural communication and English comprehensive ability, the construction of faculty and staff aiming at developing compound teachers of high qualities with rich teaching experience should be carried out in the first place. Teachers need to help students cultivate correct and objective view of cultural conflicts. It is necessary and significant that teachers never stop learning new knowledge of intercultural knowledge and updating their stock of knowledge, thus possessing high cultural attainment and capacity of understanding and expounding. Therefore, it is strongly advised that universities strengthen training of teachers, encourage teachers of linguistic majors to further their study of administration or economy, and inspire teachers to further their study abroad with relevant policies.

\subsection{Construction of Business English Teaching Materials}

The status and roles of teaching materials in teaching cannot be neglected. The success of business English teaching, to a large extent, will result from high-quality teaching materials. Nevertheless, too little research has been available to underpin teaching materials of business English. Besides lack of innovation, systematicness and authority, a further drawback is that only a fraction of the textbooks are equipped with teacher's book, workbook and other learning reverence materials.

Textbooks should cover various aspects including social culture, history culture, nature and human geography, possessing systematicness and scientificity, which can help students have an overall and systematical grasp of intercultural knowledge, avoiding superficial and one-sided understanding. Meanwhile, it is necessary to compile intercultural communication textbooks that conform to the 
tactic of business English talents cultivation based on actual situation of our country. What's more, universities can also compile school-based teaching textbooks according to local educational philosophy and the actual conditions of school, which is a feasible approach to guaranteeing teaching effect of business English intercultural communications.

Moreover, teaching textbooks written by native speakers of the target language can be introduced into our classroom. Then students can be easily put into the target setting that will definitely promote their consciousness of the foreign culture. Market Leader (4 level) and Pass Cambridge BEC (3 level) are particularly recommended both of which are published in Britain and imported into China.

\subsection{Construction of Evaluation Mechanism}

The main purpose of intercultural communication lies in making students achieve better communication in intercultural situations. Therefore, schools and teachers are required to constantly explore to provide more chances of intercultural communication for students, and pursue evaluation method which can validly assess and promote their intercultural communication competence, such as interview reports with overseas students, foreign affairs practice, business negotiation simulation. These evaluation modes can promote students' intercultural exchange and instruct them to learn about different thinking style and solutions to problems. In this way will students not only accumulate industry knowledge and experience, but also can keep sensitivity to cross-culture needed in business activities all the way.

New-style dynamic evaluation program for business practice curriculum system should be established. Through diversified and compound evaluation mechanism including teaching atmosphere, curriculum structure, teaching process, practice and exercises, bilingual teaching mode and so on. Besides, it is advisable that universities invite experienced enterprise personnel to be deeply involved in the process of teaching and evaluating. In addition, the evaluation should be composed of process assessment and summative assessment, especially with process evaluation implemented throughout the whole process of teaching. It is also suggested that the proportion of assessment for students' ICC be partly increased in the evaluation mechanism of business English teaching and learning.

\section{Conclusion}

The fast growth of economic globalization makes higher and higher demands on business English talents. Practically and theoretically speaking, developing learners' intercultural communication competence should be an inseparable part of business English education goal and universities have the responsibility to prepare their students to become effective intercultural communicators. The principles of cultivation of ICC in business English are put forward in the thesis as systematicness, practicality and comparison, which could be implemented by 
teachers in the process of education.

It seems that most teachers of business English tend to focus on business and professional knowledge teaching but don't pay enough attention to the cultivation of students' intercultural business English communication competence. One of the reasons that should not be overlooked is that for most universities there is no systematic teaching syllabus concerning the instruction and evaluation of business English intercultural communication abilities. Therefore, the enactment of scientific and systematic teaching program is regarded as the top priority for universities and colleges. Teacher is the conductor, organizer and director in the process of teaching. The cultivation of students' intercultural communication competence cannot be achieved without well-educated and highly qualified teachers. Not only should teachers transform their traditional educational concept and step out of their comfort zone, but also more training or further study abroad opportunities are supposed to be given to business English teachers. The construction of teaching materials, meanwhile, is the guarantee for teaching and learning effect. Universities and colleges are encouraged to compile their own school-based textbooks on business intercultural communication which will be more suitable for students in each university.

As a theoretical study, the limitations of this thesis cannot be neglected. To put the theory into practice, further studies of combining the theory with the actual situation are under great demand and they will enrich the teaching and learning of business English in universities. In addition, the strategies and approaches discussed by the author in the thesis are mainly made from observation, references or teaching experience, therefore, the effect of the approaches needs testing in class and further quantitative studies to improve this research.

\section{Conflicts of Interest}

The authors declare no conflicts of interest regarding the publication of this paper.

\section{References}

Chen, G. M. (1989). Relationships of the Dimensions of Intercultural Communication Competence. Communication Quarterly, 37, 118-133. https://doi.org/10.1080/01463378909385533

Chen, G. M., \& Starosta, W. J. (2000). The Development and Validation of Intercultural Sensitivity Scale. Human Communication, No.3, 1-15

Hu, G. L. (2008). Pragmatic Errors in Business English and the Cultural Analysis and Understanding. Journal of Jianghan Petroleum University of Staff and Workers, No.1, 43-46.

Hu, W. Z. (1999). Intercultural Communication Series. Beijing: Foreign Language Teaching and Research Press.

Kim, Y. Y. (2001). Becoming Intercultural: An Integrative Theory of Communication and Cross-Cultural Adaptation. Thousand Oaks, CA: Sage Publication, Inc.

Krober, A., \& Kluckhohn, C. (1954). Culture: A Critical Review of Concepts and Defini- 
tions. The Journal of Philosophy, 51, 559-563. https://doi.org/10.2307/2021459

Shen, X. E. (1997). The Cultivation of Business English Talents Based on the Perspective of Intercultural Communication. Business and Trade Talent, No.5, 190-191.

Wang, L. F. (2015). The Interpretation of Main Points of National Standard for Undergraduate Teaching Quality of Business English Majors. Foreign Language Teaching and Research, No.2, 297-302.

Yang, X. Q. (2015). Adult Business English and the Cultivation of Intercultural Business Communication Competence. China Adult Education, No.13, 165-167.

Zeng, W. X. (2002). Teaching Studies on Business English. Journal of Jiangxi Science and Technology Normal University, No. 4, 85-87.

Zhang, X. Y. (2020). The Development of Business English Teachers' Professional Ability under the "National Standard". Overseas English, No. 22, 164-165.

Zhao, J. J. (2020). An Empirical Study on Cross-cultural Competence Cultivation in the Course of "Integrated Business English" under the Paradigm of "Curriculum-Integrated Ideological and Political Education". Journal of Zhejiang Wanli University, 33, 49-53. 